\title{
Measuring Students Environmental Problem Solving Ability Across Gender and School Differences Using Paper Based Testing
}

\author{
https://doi.org/10.3991/ijet.v15i13.11709 \\ Ridhwan \\ Universitas Negeri Malang, Malang, Indonesia \\ STKIP Al-Washliyah, Banda Aceh, Indonesia \\ Sumarmi, I Nyoman Ruja, Dwiyono Hari Utomo \\ Universitas Negeri Malang, Malang, Indonesia \\ Rima Meilita Sari $(\bowtie)$ \\ STKIP Al-Washliyah, Banda Aceh, Indonesia \\ rima.sari2121@gmail.com
}

\begin{abstract}
This study aimed to describe the environmental problem solving ability, analyze differences in the environmental problem solvng ability when viewed from gender and school differences. To test the environmental problem solving ability in students, a test instrument that refered to the Sanjaya's indicator was developed. The test items were developed by researchers and validated by material and language experts. After revising the results of expert validation, the test of the environmental problem solvng ability was tested. The trial results obtained a test instrument that was valid and reliable. Quantitative data were obtained from the answers of 136 students to the problem solving ability test. The results showed that: 1 ) the environmental problem solving ability in students was still low, 2) there is no relationship between gender differences and the environmental problem solvng ability. 3) there is no relationship between school differences and problem solving abilities. Further researchers are suggested to facilitate students through teaching materials in the implementation of learning and increase student activity in learning activities in order to improve the environmental problem solving ability.
\end{abstract}

Keywords—Environmental Problem Solving, Gender, Schools, Paper Based Testing

\section{Introduction}

Technological developments cause rapid changes in human life. Positive influences arising from technological advances are easy access to information and other facilities that support human lifestyles [1] [2]. Furthermore, the use of technology in learning 
can enhance learning experiences [3]. Technological developments that enter the world of learning, create new challenges in learning [4].

In addition to having a positive influence on human life, technological progress also has a negative effect. One of them is a change in environmental aspects [5] [6]. Cases that occur are environmental degradation and air pollution that triggers global warming [7].

The current rapid environmental degradation must be taken seriously. This is because environmental changes are associated with changes in biotic and abiotic aspects [8]. Therefore, to deal with environmental changes, especially in the case of environmental degradation, the environmental problem-solving ability is needed [9].

The environmental problem solving ability has become the focus of attention of researchers around the world to be studied and developed. Various studies examine the importance of problem solving learning in the field of Education by developing models, mobile-based learning technologies in environmental learning, and ecological approaches to learning to overcome environmental degradation in the 21 st century, which are carried out at various levels of Education [10 -16].

From previous research, it can be concluded that the environmental problem solving ability can be taught through formal education. In recent years, the Indonesian government has focused on developing the environmental problem solving ability in formal education. The development of problem solving abilities is in line with the goals of $21 \mathrm{st}$ century learning, namely developing critical thinking skills and problem solving, communication, collaboration, creativity and innovation [17]. One subject that has a focus on developing problem solving abilities is geography because geography examines geospheric phenomena through spatial, regional and ecological perspectives [18]. Learning geography that aims to develop the environmental problem solving ability can be done through the process of constructing old knowledge and experience with new knowledge and experience [19] [20]. Geography learning can be used to develop problem-solving skills through contextual learning [5].

Based on indicators of problem solving ability, this study investigated the initial environmental problem solving ability. It aimed to obtain a picture and solution to develop problem solving skills. Furthermore, this study was also conducted to find out whether there were differences in problem solving abilities in different genders and schools.

Measuring the environmental problem solving ability requires the development of test instruments for the environmental problem solving ability. This is due to the lack of instruments to measure the environmental problem solving ability in accordance with the character of students in Indonesia. In addition, studies on the level of students' environmental problem solving abilities are still very rarely found. Therefore, this study sought to complement the research conducted by previous researchers in measuring environmental problem solving abilities and the level of environmental problem solving abilities of students and reviewing differences in abilities based on differences in genders and schools.

There are several topics explored in this article, namely the elaborating of the theoretical basis, proposing hypotheses, elaborating methodologies and instruments of development, results and evaluations, and discussion. The article also discussed the limitations of research and suggestions for future research. 


\section{Theoretical Background}

\subsection{The Relation between Environmental Problem Solving Ability and} Environmental Education in Geography Learning

Basically, environmental education is an educational process that aims to impove people to be aware of and care for the environment and all matters relating to the environment, both separately and in relation to humans [21] [22]. In Indonesia, environmental education received attention from 1977, then, environmental education was included in formal education in 1986 in the subject of population and environmental education. In 2006, the Indonesian government developed the "adiwiyata" green school program as a platform for environmental education learning for students. [23]. In accordance with the development of the 21 st century, environmental education is the main focus in the framework of Education in Indonesia as the main goal of learning, namely overcoming environmental problems, especially in Adiwiyata schools [24]. In this case, geography learning is included in the framework of environmental subjects with the type of problem being taken that is not well structured. Unstructured problems are concerned with aspects of the process in solving problems [25]. The scope of geography studies in assessing the environment can be seen in Figure 1.

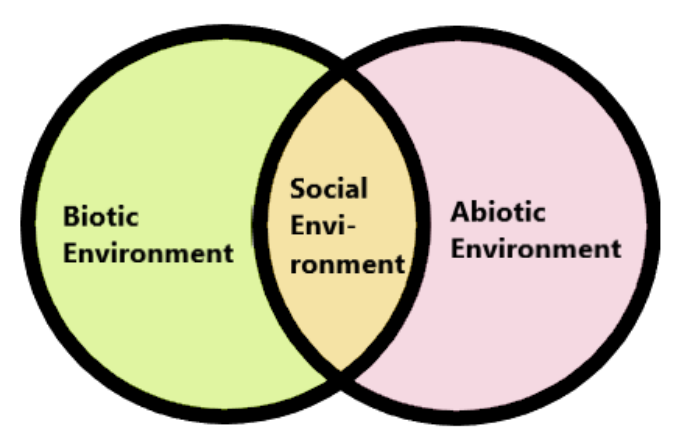

Fig. 1. The scope of the Geography Study in Assessing the Environment [26] is modified

The constructivist theory in environments learning for environmental sustainability requires a direct approach where students learn and interact [27]. The constructivist theory in environmental education is widely taught through a form of investigation of environmental problems through teachers and students [28] [29]. Learning is done through in-depth discussions and investigations even related to past experiences that are connected with findings that occur today.

Furthermore, there are other ways used by previous researchers to implement environmental education into learning through the adoption of technology, delivery of information, as well as the implementation of learning tools and learning models [10-16]. Environmental education in its relationship with the inculcation of the environmental problem solving ability in the face of environmental degradation becomes one of the interesting studies to study. 
Paper-Measuring Students Environmental Problem Solving Ability Across Gender and School Diff..

\subsection{The Environmental Problem Solving Ability and Personal Factors of Students}

In the last few decades, one of the most important problems that has become the focus of immediate resolution is environmental problems [30]. Therefore, the problem solving ability is very important to be taught to students in learning activities. By the environmental problem solving ability, students can foster environmental awareness through a responsible attitude towards the environment [30-32]. Through cognitive aspects that are taught in class, students have the ability to provide solutions and are skilled to choose the best solution and other alternatives if the solution cannot be implemented properly [32-34]. The solution chosen also requires students' ability to recognize problems such as finding causes, correctness of information, and the consequences of each solution [35].

The importance of mastering the environmental problem solving ability encourages the teacher to provide a situation to achieve learning goals. Situations that support environmental problem solving activities should adjust to the conditions experienced by students [34] [36]. Contextual conditions become the initial stimulus so that it can improve scientific attitudes and student achievement [37]. Therefore, learning aimed at solving environmental problems must link the problem being solved to the environment in which the student is active.

Students have an important role in implementing problem solving learning. This relates to self-will and self-sensitivity of students in dealing with problems in the environment [29]. Self-motivation is related to the goal of carrying out problem solving activities [38]. Internal factors such as student personality from individual preference theory have been investigated to find out how influential personalities such as the mental processes of sensing, intuition, thinking, and feeling influence decision making [3941].

Student demographic factors such as gender have been discussed in some of the earlier literature in relation to problem-solving abilities and the extent to which gender influences problem-solving abilities [42-49]. Research on gender and its relationship to problem solving skills alludes to the fact that men are superior in problem solving [42] [44] [45] [48] [49]. Other studies explain that it is women who are actually superior to men in problem solving [46]. On the other hand, other studies did not find any gender differences in problem solving abilities [43] [47].

External factors are also discussed in this study about how influential factors from outside students in problem solving skills. External factors such as teacher teaching methods and the learning environment are considered as factors that influence the problem solving ability [50] [51]. Researchers focus on external factors such as the learning environment especially schools. School is considered as an environment that is relevant to students' life, considering that students spend a lot of time in school studying and interacting [52]. 


\subsection{Research Models and Hypotheses}

The problem solving ability is very important for students to face the rapid technological development because by teaching the environmental problem solving ability to students, they will get used to doing thinking activities to solve problems. It motivates researchers to conduct research that aimed to determine the students environmental problem solving ability. Furthermore, this study involved two variables that influence the problem solving ability. Researchers examined internal factors, namely gender and external factors, namely schools as factors that influenced the environmental problem solving ability. Therefore, researchers try to delivered the following questions:

- How are students'environmental problem solving abilities?

- Are there differences in the environmental problem solving abilities across gender differences?

- Are there differences in the environmental problem solving abilities across school differences?

\section{Methodology}

The research conducted refered to a survey of the environmental problem solving ability. The study used quantitative data collection methods conducted by distributing tests of problem solving abilities to high school students who are the research subjects.

The results of data collection produce data on the environmental problem solving ability. To answer research questions about how the environmental problem solving ability, the data obtained from environmental problem solving ability were then analyzed using descriptive statistics. The criteria for the level of problem solving ability were known by calculating the total score obtained by students. The score results were categorized into five categories: very low, low, medium, high, and very high. To find out the environmental problem solving ability of all students, the average student was calculated. The details of the five criteria for students' environmental problem solving abilities can be seen in Table 1 .

Table 1. Criteria of the Environmental Problem Solving Ability

\begin{tabular}{|c|c|}
\hline Environmental Problem Solving Ability Scores & Criteria \\
\hline $0-20$ & Very Low \\
\hline $21-40$ & Low \\
\hline $41-60$ & Medium \\
\hline $61-80$ & High \\
\hline $81-100$ & Very High \\
\hline
\end{tabular}

To complete the analysis, descriptive statistics, mean values, and standard deviations are also expressed, for each question and indicator of problem solving ability. To answer the second and third questions related to problem solving skills when viewed from different genders and schools, the analysis required Mann Whitney assisted with SPSS 23 for Windows. 


\section{$4 \quad$ Instrument}

To find out the environmental problem solving ability, an instrument to test environmental problem solving abilities was developed. The instrument developed was related to environmental issues contextually. The Sanjaya's indicators [53] were used as an indicator of problem solving ability. The question contained five sub-indicators: 1) formulating problems, 2) formulating hypotheses, 3) collecting data 4) testing hypotheses, and 5) providing problem solving recommendation [53]. The instruments were prepared using two experts in the field of Languages and geographic resources. The questions consisted of 10 question items with scores adjusted to the level of difficulty for each question item.

After developing the question items, the steps taken were validating the test items. Expert validation aimed to test whether the instrument developed has language clarity and the suitability of the material with learning, so that the instrument can be applied to students [54]. The results of expert validation showed that the test instrument for problem solving ability was ready to be tested with several improvements such as the use of language that is easier to understand, more systematic sequence of questions, and adjustment to the concept of learning.

Before the test is widely implemented, a preliminary study was conducted to test wheather the questions had been clear and easily understood. The study was conducted for 1 week. The trial involved 30 students. The trial phase produced as many as 10 valid question items with a validity range of $0.527-0.780$. Test instruments also obtained reliable results with Cronbach's alpha values $>\mathrm{r}$ table $(0.876>0.361)$. The details of test items, validity values, and reliability can be seen in Table 2 .

Table 2. Indicators, Questions, Validity, and Reliability of Test Instruments of Environmental Problems Solving Ability

\begin{tabular}{|c|c|c|c|c|}
\hline Indicators & No. & Questions & Validity & Reliability \\
\hline $\begin{array}{l}\text { Formulating the } \\
\text { problem }\end{array}$ & 1 & What are the problems on the passage? & 0,527 & 0,874 \\
\hline \multirow{3}{*}{$\begin{array}{l}\text { Formulating hy- } \\
\text { potheses }\end{array}$} & 2 & What are the factors that cause these problems? & 0,780 & 0,855 \\
\hline & 3 & $\begin{array}{l}\text { What will happen if the problem is not resolved imme- } \\
\text { diately? }\end{array}$ & 0,767 & 0,858 \\
\hline & 4 & What is a solution to deal with problems in passage? & 0,780 & 0,855 \\
\hline Collecting data & 5 & $\begin{array}{l}\text { Are there any difficulties that will be encountered to } \\
\text { deal with the problem? }\end{array}$ & 0,703 & 0,862 \\
\hline \multirow{3}{*}{$\begin{array}{l}\text { Testing the hy- } \\
\text { potheses }\end{array}$} & 6 & What is the best solution to overcome these problems? & 0,767 & 0,858 \\
\hline & 7 & $\begin{array}{l}\text { What is the strengths and weaknesses of the solutions } \\
\text { provided? }\end{array}$ & 0,780 & 0,855 \\
\hline & 8 & $\begin{array}{l}\text { Based on your choice, how is a practical way to solve } \\
\text { the problem? }\end{array}$ & 0,703 & 0,863 \\
\hline \multirow{2}{*}{$\begin{array}{l}\text { Providing problem } \\
\text { solving recom- } \\
\text { mendation }\end{array}$} & 9 & $\begin{array}{l}\text { If the solution given has constraints, is there an alterna- } \\
\text { tive solution to overcome the problem? }\end{array}$ & 0,534 & 0,877 \\
\hline & 10 & How are alternative solutions to solve the problem? & 0,527 & 0,874 \\
\hline
\end{tabular}


The trial results show ten items of environmental problem solving ability test were valid and reliable. Each question item related to a mass media article entitled "Coal and Environmental Damage". The selection of the title was based on the characteristics of the environment in which students live, namely in the city of Banjarmasin that was surrounded by coal mining locations. Therefore, it was very close to the student's living environment. Based on the results of the trial, the instrument test was ready to be implemented on the research subject. The trial was conducted on geography subjects for 2 hours of learning $(2 \times 45$ minutes $)$.

\subsection{Characteristics of Research Subjects}

To determine students' environmental problem solving ability, research involved gender and school variables. The research subjects were selected from two schools that represented the geographical characteristics of the Banjarmasin city, Indonesia. Different characteristics can be seen in the northern and southern parts of Banjarmasin City. The 69 students were taken as samples. They were from Senior High School A that is located in the northern part of the suburbs with a neighborhood of schools in the form of housing. Meanwhile, the 67 students who were taken as samples were from Senior High School B. it is located in the southern part of the suburbs, the neighborhood around the school is dominated by swamp land which is used as rice fields. The selection of high schools in Banjarmasin was based on the consideration that high schools in Banjarmasin are among the learning development projects in Indonesia. The number of samples in the two schools consisted of 72 male students and 64 female students. Based on ethical considerations and the privacy interests of students and schools as research subjects, personal data of students and schools must be carefully calculated during the research process.

The study was conducted for 3 months from October to December 2018. Before conducting the study, researchers obtained research permission at the research subject school. Before heading to the school, the researchers came to the South Kalimantan Province Education Office to complete the administration and obtain the main data as a reference for the selection of schools of research subjects. The study was conducted on the material "natural resources" with a time allocation of 4 x 45 minutes per week for two months. Subjects were asked to answer environmental problem solving tests with direct supervision from a geography teacher. The geography teacher collected the results of the test ban and returned it to the researcher for analysis. Before the study, the researcher gave guarantees the confidentiality and anonymity of the data to the research subjects.

\subsection{Analysis of Research Results Data}

Tests on the environmental problem solving ability that had been developed were then implemented on the research subjects. A total of 72 male students $(53 . \%$ of the study sample) and 64 female students (47\%) from two schools that have different geographical locations were included. Students were categorized based on two variables 
namely gender (male and female) as internal variables and school location (High School A and High School B) as external variables.

In the ability to formulate problems, students both viewed from the gender type and the school showed the same category score with a total score of 92.65 , which means the ability to formulate problems in very high criteria, this means that students had been skilled in formulating problems and recognizing problems that will be solved. Then, the ability of students to formulate hypotheses and collect data had decreased but it is still in the high category (62.72 for formulating a hypothesis and 69.49 for collecting data). The results of the ability to test hypotheses and recommend problem solving solution both have low criteria (29.03 for testing problems and 14.04 for providing problem solving recommendation). This means students had difficulty with the ability to test hypotheses and recommend problem-solving solutions. This finding shows that all students of both genders and schools have difficulty in solving environmental problems (total score $=38.50$, low criteria) $($ see table 3$)$.

Table 3. Environmental Problem Solving Ability

\begin{tabular}{|l|c|c|c|c|c|c|}
\hline \multirow{2}{*}{ Variable } & \multicolumn{5}{|c|}{ Indicator of Environmental Problem Solving Ability } & \multirow{2}{*}{ Total } \\
\cline { 2 - 6 } & $\begin{array}{c}\text { Formulating } \\
\text { problem }\end{array}$ & $\begin{array}{c}\text { Formulating } \\
\text { hypothesis }\end{array}$ & $\begin{array}{c}\text { Collecting } \\
\text { data }\end{array}$ & $\begin{array}{c}\text { Testing the } \\
\text { hypothesis }\end{array}$ & $\begin{array}{c}\text { providing prob- } \\
\text { lem solving rec- } \\
\text { ommendation }\end{array}$ & \\
\hline Male & 93,89 & 61,04 & 67,78 & 28,33 & 13,24 & 37,57 \\
\hline Female & 91,25 & 64,61 & 71,41 & 29,82 & 14,95 & 39,55 \\
\hline A & 98,26 & 65,65 & 71,74 & 29,44 & 14,01 & 39,72 \\
\hline B & 86,87 & 59,70 & 67,16 & 28,61 & 14,08 & 37,24 \\
\hline
\end{tabular}

To examine the ability to solve environmental problems more specifically, descriptive statistics were used for each indicator and question items on the test. Table 4 shows the average range of 2.28 to 12.43 . The total number of scores for each indicator is taken from the sum of each test item. In more complex problem solving skills, the mean decreases in each test item. This can clearly explain that in the increasingly complex question items, students find it very difficult to give the targeted answer, namely the ability to present environmental problem solutions $(\mathrm{M}=4.21, \mathrm{SD}=3.667)$. The findings are presented in Table 4.

To answer questions about differences in the environmental problem solving ability in different genders, researchers used non-parametric non-parametric statistical tests using the Mann Whitney $U$ test. This was chosen after drawing conclusions that the research data were not normally distributed. Whitney $U$ test was assessed based on the total score and items per indicator of the environmental problem solving ability. The results showed that the environmental problem solving ability of female students was higher $(\mathrm{M}=73.09, \mathrm{SD}=9,257)$ compared to male students $(\mathrm{M}=64.42, \mathrm{SD}=9,257)$. However, if assessed from differences in the environmental problem solving ability, there was no significant differences between male and female students (Sig $(2$ tailed $)=$ $0.119, \mathrm{p}>0.05)$.

The results of a more in-depth analysis of each indicator (formulating problems, formulating hypotheses, collecting data, testing the hypotheses, recommending problem solving solution) find the same thing that there is no significant difference. If examined 
more deeply on each indicator of problem solving ability, female students are superior than male students in the indicators formulating hypothesis, collecting data, and testing the hypothesis. The detail results of the study can be seen in Table 5.

Table 4. Statistical Descriptions on Indicators of Environmental Problem Solving Ability

\begin{tabular}{|c|c|c|c|c|c|c|}
\hline Indicator & Min & Max & M & SD & Skewness & Kurtosis \\
\hline Formulating Problem (FP) & & & 4.63 & 0,778 & $-1,651$ & 0,736 \\
\hline FP 1 & 3 & 5 & 4,63 & 0,778 & & \\
\hline Formulating Hypotesis (FH) & & & 12,43 & 3,110 & 0,105 & 0,188 \\
\hline FH 1 & 1 & 5 & 4,01 & 1,047 & & \\
\hline FH 2 & 1 & 5 & 3,83 & 1,407 & & \\
\hline FH 3 & 1 & 10 & 4,59 & 2,165 & & -1.250 \\
\hline Collecting Data (CD) & & & 6,95 & 2,819 & $-0,114$ & \\
\hline CD 1 & 1 & 10 & 6,95 & 2,819 & & \\
\hline Testing the Hypothesis (TH) & & & 10,16 & 4,324 & 0,481 & \\
\hline TH 1 & 1 & 10 & 4,36 & 2,415 & & \\
\hline TH 2 & 1 & 10 & 3,52 & 2,018 & & 2,872 \\
\hline TH 3 & 1 & 5 & 2,28 & 1,444 & & \\
\hline $\begin{array}{c}\text { Providing Problem Solving } \\
\text { Recommendation (PPSR) }\end{array}$ & & & 4,21 & 3,667 & \multirow{2}{*}{1,978} & \\
\hline PPSR 1 & 1 & 10 & 2,49 & 2,613 & & \\
\hline PPSR 2 & 1 & 5 & 1,73 & 1,250 & & \\
\hline
\end{tabular}

Table 5. Mann-Whitney Non-Parametric Statistical Test Results on Gender Differences on the Environmental Problem Solving Ability

\begin{tabular}{|c|c|c|c|c|c|c|c|}
\hline \multirow[t]{2}{*}{ Indicator } & \multicolumn{2}{|c|}{ Mean Range } & \multirow[t]{2}{*}{ SD } & \multirow{2}{*}{$\begin{array}{c}\text { Mann- } \\
\text { Whitney U }\end{array}$} & \multirow[t]{2}{*}{ Wilcoxon W } & \multirow[t]{2}{*}{$\mathbf{Z}$} & \multirow{2}{*}{$\begin{array}{c}\text { Asymp. Sig } \\
\text { (2-tailed) }\end{array}$} \\
\hline & Man & Woman & & & & & \\
\hline Formulating problem & 70.61 & 66.13 & 0.778 & 2152.000 & 4232.000 & -.988 & .323 \\
\hline Formulating hypothesis & 65.47 & 71.91 & 3.329 & 2085.500 & 4713.500 & -.962 & .336 \\
\hline Collecting data & 66.49 & 70.77 & 2.819 & 2159.00 & 4787.000 & -.712 & .476 \\
\hline Testing the hypothesis & 65.58 & 71.78 & 4.324 & 2094.000 & 4722.000 & -.920 & .358 \\
\hline $\begin{array}{l}\text { providing problem solv- } \\
\text { ing recommendation }\end{array}$ & 70.52 & 66.23 & 3.666 & 2158.500 & 4238.500 & -.685 & .493 \\
\hline
\end{tabular}

Researchers also used a non-parametric statistical test analysis using the Mann Whitney $U$ test to differences in the environmental problem solving ability based on different school locations. Schools were categorized in High School A, which is located in the north of the city (residential neighborhood) and High School B, which is located in the south of the city (housing and rice fields). The results of the environmental problem solving ability at school $\mathrm{A}$ are higher $(\mathrm{M}=73.72, \mathrm{SD}=9,257)$ compared to school $\mathrm{B}$ $(\mathrm{M}=63.13, \mathrm{SD}=9,257)$. However, there is no significant differences were found between School A and School B in the environmental problem solving ability (Sig (2 tailed) $=0.117, \mathrm{p}>0.05)$.

The findings analyzed more specifically show that although there is no significant difference between high school A students and high school B students, the ability to formulate problems and formulate hypotheses is significant. Significance value is (sig $(2$ tailed $)=0,000, \mathrm{p}<0.05)$ and formulating hypothesis $(\operatorname{sig}(2$ tailed $)=0.044, \mathrm{p}<0.05)$ between high school A students and high school B students prove specific differences. 
The results of the Mann-Whitney test are presented in Table 6. Even if traced in more detail, High School A students outperformed High School B students over all indicators of environmental problem solving ability, ability to formulate problems, and the ability to form hypotheses. This means that compared to High School B students, High School A students tend to have the ability to formulate problems $(\mathrm{M}=78.04 \mathrm{SD}=0.778)$ that is better than High School B students $(\mathrm{M}=58.67, \mathrm{SD}=0.778)$. Similarly, high school A students also excels at the ability to formulate hypotheses $(\mathrm{M}=75.15, \mathrm{SD}=3.329)$ compared to High School B students $(\mathrm{M}=61.65, \mathrm{SD}=.3,329)$. In other indicators, it can also be seen that high school A students outperformed high school B students. This finding shows that in the environmental problem solving ability, high school A students are superior compared to high school B students. (Data in table 6).

Table 6. Non-Parametric Statistical Test Results of School Differences on the Environmental Problem Solving Ability

\begin{tabular}{|l|c|c|c|c|c|c|c|}
\hline \multirow{2}{*}{ Indicator } & \multicolumn{2}{|c|}{ Mean Range } & SD & Mann-Whitney & Wilcoxon W & Z & $\begin{array}{c}\text { Asymp. Sig } \\
\text { (2-tailed) }\end{array}$ \\
\cline { 2 - 7 } & $\boldsymbol{A}$ & $\boldsymbol{B}$ & & $\mathbf{U}$ & & & .000 \\
\hline Formullating problem & 78.04 & 58.67 & 0.778 & 1653.000 & 3931.000 & -4.272 & .044 \\
\hline Formulating hypothesis & 75.15 & 61.65 & 3.329 & 1852.500 & 4130.500 & -2.019 & .431 \\
\hline Collecting data & 70.83 & 66.10 & 2.819 & 2151.000 & 4429.000 & -.787 & .665 \\
\hline Testing the hypothesis & 69.93 & 67.02 & 4.324 & 2212.500 & 4490.500 & -.433 & .749 \\
\hline $\begin{array}{l}\text { providing problem solv- } \\
\text { ing recommendation }\end{array}$ & 69.49 & 67.49 & 3.666 & 2243.500 & 4521.500 & -.320 &. \\
\hline
\end{tabular}

The environmental problem solving ability developed through paper-based test items has been successfully implemented and obtained results that can measure the environmental problem solving ability of high school students. Students showed problemsolving abilities in the low category (total score of 38.50 in the low category). Table 5 shows no differences in problem solving abilities between male and female students $(\operatorname{Sig}(2$ tailed $)=0.119, \mathrm{p}>0.05)$. Furthermore, table 6 shows the findings also revealed no difference when viewed from the school (Sig $(2$ tailed $)=0.117, \mathrm{p}>0.05)$.

\section{Discussion}

The need for the environmental problem solving ability increases along with the development of science and technology. This causes the need to increase the ability to think at a higher level, which refers to the ability to provide solutions to problems [55]. In the field of Education, the teacher believes that through students who are skilled at solving environmental problems, students will easily adapt to real life [12]. For this reason, learning that teaches the natural environment in the classroom and outside the classroom is needed [56]. Before conducting the study, the researcher managed to develop an instrument to measure the environmental problem solving ability by referring to the Sanjaya's indicators. The choice of indicators was due to the characteristics of high school students. Several previous studies have strengthened the reason why these indicators were chosen to be developed into a test instrument in research [57] [58]. 
In general, students still have difficulty in thinking to solve environmental problems [59]. The result of the investigation found that students' weaknesses in solving problems is less sensitive to what was happening in the surrounding environment. This is influenced by several factors both inside and outside the student. From the inside, the problem is unfamiliarity and lack of sensitivity to the environment [60]. Students are lack knowledge of the latest information, even though information technology has been highly developed. The use of information technology via smartphones mostly to access online games. From the outside, the problem is learning that only memorizes many concepts, but does not connect to contextual problems to be solved by students. Memorization activities hinder the activeness of students interacting with the environment. This is supported by research [61], which explains that active learning can have an impact on increasing students' chances of learning more.

Furthermore, the variable environmental problem solving ability, such as gender and school location, has been explained in the research literature regarding the relationship between these variables and the ability to solve environmental problems. If both gender variables and school location are explained, all indicators are very low except indicator formulating problems because the problem solving ability was rarely done so that it is difficult for students to provide solutions about environmental problems. The results prove the null hypothesis and show no difference between male and female students in the environmental problem solving ability. The conclusion from the results of the influence of gender differences on the environmental problem solving ability is in accordance with the objectives and research hypotheses. The results show that the significance value is more than 0.05 . The results of the study are in line with other studies which state that there is no difference in the problem solving ability when viewed from gender differences [43] [47].

The rejection of the research hypothesis is caused by another factor, namely the learning process. Learning applied by the teacher is without distinguishing gender in the class. The teacher provides teaching material, time allocation, and evaluation of the same learning without differentiating gender. However, research [42] [44-46] [48] [49] challenges the research findings. The research results [42] [44] [45] [48] [49] showed that men are superior in problem solving while research [46] states women are superior to men in problem solving.

The second hypothesis obtained the results of rejection of the hypothesis, which means there is no influence of school differences with the problem solving ability. The results of the proposed hypothesis were based on the research objectives. Evidence shows that the significance value of the Mann Whitney test results shows a significance greater than the proposed significance level (0.05). Although the indicators of formulating problem and formulating hypotheses show that there are differences in terms of school differences, they have not yet fulfilled the requirements for all environmental problem solving ability.

This is because the location of the school has the same characteristics, which are in the suburbs. The two research subject schools have similarities in terms of environmental, accessibility and facilities aspects. This is supported by research [62] [63], which states that the same environment, accessibility and facilities affect learning outcomes. The environmental problem solving ability between students of school A and B is still 
low because both school locations are on the suburbs with limited access and learning facilities. This is supported by [64] which states that schools located in the suburbs have lower grades than students who study in the city center.

\section{$6 \quad$ Limitations and Future Research}

The author realizes this research still has limitations. Efforts to correct the shortcomings of this research will be refined in further research in the future. The limitations obtained are related to sample problems, instrument testing, and research variables. First, this research was limited to class XI students from three high schools in Banjarmasin. The small number of samples caused the results of the study could not be generalized widely throughout Banjarmasin City, Indonesia. Research was limited to high school students in Banjarmasin City. Second, instrument testing has procedures that can be carried out in the field, but testing the validity and reliability of the instrument has limitations with a small number of test subjects. Testing instruments without looking at gender and school factors causes the instrument to be general in nature. Third, research was limited to internal factors such as gender, and school factors. Other variables that influence the environemental problem solving ability are not involved causing conclusions obtained only from two factors (gender and school).

The limitations of this study have implications for future research. For future research, it is expected to expand research subjects that are not limited to the scope of one city. It is necessary to cross cities to generate better research. Furthermore, further research is needed at the elementary school, junior high school and university level. Instrument development is expected to answer the variables studied according to the characteristics of the subject. Furthermore, future research is expected to involve other variables that affect the ability to solve environmental problems.

\section{Conclusion}

The importance of the environmental problem solving ability has become the focus of attention of previous research to examine as has been stated in the introduction and supporting literature of this paper. The development of industrialization and modernity of human life has directly affected the environment. Most influences on industrialization and modernization in this century are destructive, giving rise to other effects of the process of environmental degradation [33]. The environmental problem solving ability needs to be taught through Education [65].

The purpose of this study was to determine the level of students' environmental problem solving abilities, and to investigate the effects of gender and school differences and identify the extent to which these factors influence the environmental problem solving ability. The results of the study show that the level of environmental problem solving ability in students is still low. Furthermore, gender and school factors were not found to influence the environmental problem solving ability.

The environmental problem solving ability in students still needs to be improved. Some recommendations were mentioned in previous studies to improve the problem 
solving ability, especially in learning activities in the classroom [66-73]. Growing sensitivity to environmental problems is important for students to do. In this case, technological development must be utilized. Learning environment that uses technology, will increase the effectiveness of learning [16]. This also influences student interest [73]. In this context, guidance from teachers is needed to oversee technology-based learning so that learning goals to solve environmental problems can be more meaningful. Furthermore, teachers should consider the internal factors of students in learning activities. Student internal factors can be used as a reference for treatment of student problems, especially for each individual student.

This research was expected to be the basis of steps to develop the environmental problem solving ability through education. Research can help teachers as a foundation for the environmental problem solving ability that need more attention when viewed from each indicator. Furthermore, this research can provide input to teachers to adopt good learning in order to improve their environmental problem solving ability.

\section{Acknowledgment}

The authors' gratitude is for the Department of Geography, Faculty of Social Sciences, Universitas Negeri Malang. The authors also thank to LPDP (The Indonesia Endowment Fund for Education) through the BUDI DN program for sponsoring the researchers during the study at the Department of Geography, Faculty of Social Sciences, Universitas Negeri Malang.

\section{$9 \quad$ References}

[1] Hanafizadeh, P., Ghandchi, S., Asgarimehr, M. (2017). Impact of Information Technology on Lifestyle: A literature Review and Classification. International Journal of Virtual Communities and Social Networking, 9 (2): 1-24.

[2] Ebrahimi, M. R., Toroujeni, S. M. H. \& Shahbazi, V. (2019). Score Equivalence, Gender Difference, and Testing Mode Preference in a Comparative Study Between Computer-Based Testing and Paper Based Testing. International Journal of Emerging Technologies in Learning, 14(7), 128 - 143. https://doi.org/10.3991/ijet.v14i07.10175

[3] Papadakis, S. (2018). Evaluating Pre-Service Teachers' Acceptance of Mobile Device With Regards to Their Age and Gender: A Case Study in Greece. International Journal of Mobile Learning and Organisation, 12(4), 336-352. https://doi.org/10.1504/IJMLO.2018.095130

[4] Papadakis, S. (2016). Creativity and Innovation in European Education. 10 years eTwinning. Past, Present, and the Future. International Journal of Technology Enhanced Learning, 8(3/4), 279-296. https://doi.org/10.1504/IJTEL.2016.082315

[5] Sumarmi, \& Amirudin, A. (2014). Pengelolaan Lingkungan Berbasis Kearifan Lokal. Malang: Aditya Media Publishing.

[6] Sumarmi, (2015). Local Wisdom of Osing People in Conserving Water Resources. Komunitas: International Journal Of Indonesian Society And Culture, 7(1), 43. https://doi.org/10.15294/komunitas.v7i1.3429

[7] Polaiah, D. S. (2016). Impact of Technology on Environment. International Journal of Engineering Science Invention, 5(12), 53-33

[8] Seebacher, F. \& Franklin, C. E. (2012). Determining Environmental Causes of Biological Effect: The Need For A Mechanistic Physiological Dimension in Conservation Biology. 
Paper-Measuring Students Environmental Problem Solving Ability Across Gender and School Diff...

Philosophical Transactions of the Royal Society B, 367(1596), 1607-1614. https://doi.org/10.1098/rstb.2012.0036

[9] Ismail, N. S., Harun, J., Zakaria, M. A. Z. M., \& Salleh, S. M. (2018). The effect of Mobile Problem-Based Learning Application Dic Science PBL On Students' Critical Thinking. Thinking Skills and Creativity, 28, 177-195. https://doi.org/10.1016/j.tsc.2018.04.002

[10] Shu, T., Xuejun, W., Jianying, H., Fuliu, X., Wenxin, L., Bengang, L., Jun, C. (2004). Environmental geography in China: Retrospect and Prospect. Journal of Geographical Science. 14, 74-78. https://doi.org/10.1007/BF0284111

[11] Singh, K. (2009). Environmental Degradation and Measures for its Mitigation with Special Reference to India's Agricultural Sector. India Journal of Agriculture and Economic. 64(1). $40-61$.

[12] Yurttas, G. D., \& Sulun, Y. (2010). What are the Most Important Environmental Problem According to Second Grade Primary School Student?. Procedia Social and Behavioral Sciences, 2. 1605 - 1609. https://doi.org/10.1016/j.sbspro.2010.03.244

[13] Breslin, D., \& Jones, C. (2014). Developing an Evolutionary/Ecological Approach In Enterprise Education. The International Journal of Management Education. 12(3), 433-444. https://doi.org/10.1016/j.ijme.2014.05.010

[14] Irianto, D., M., Nadiroh, Nuryadin, S. (2015). Pengaruh Model Pembelajaran dan hasil Belajar IPS terhadap Kemampuan Memecahkan Masalah Lingkungan Hidup. Pendidikan Ling$\begin{array}{llll}\text { kungan dan Pembangunan 16(2). 122-142. } & \end{array}$ https://doi.org/10.21009/PLPB.162.05

[15] Febriasari, L. K., \& Supriatna, N. (2017). Enhance Environmental Literacy through Problem Based Learning. IOP Conferece Series: Journal of Physics 895, 1-6. https://doi.org/10.1088/1742-6596/895/1/012163

[16] Kalogiannakis, M. \& Papadakis, S. (2017). Combining Mobile Technologies in Environmental Education: a Greek Case Study. International Journal Mobil Learning and Organisation, 11(2), 108-130. https://doi.org/ 10.1504/IJMLO.2017.084272

[17] Sari R M, Sumarmi, Astina I K, Utomo D H. (2019). Geography Teachers Perception on the Implimentation of Mind Map on Scientific Approach. Advances in Social Science, Education, and Humanities Research 320, 125 - 131. https://doi.org/10.2991/icskse-18.2019.24.

[18] Amin, S. (2017). Pengaruh Model Pembelajaran Problem Based Learning Terhadap Kemampuan Berpikir Kritis dan Hasil Belajar Geografi. Jurnal Pendidikan Geografi, 4(3), 2536.

[19] Schunk, D.H. (2012). Learning Theories: An Educational Perspective, Sixth Edition, 6th ed. Pearson Education.

[20] Tekes, H., \& Gonen, S. (2012). Influnce of V- Diagram on 10th Grade Turkish Students' Achievement in the subject of Mechenical Waves. Science Education International, 23(3), 268-285.

[21] UNESCO. (2011). L'education Relative a l'Environnement: Principes D'eisegnement et D'apprentissage: Programme International. Paris, France: Unesco.

[22] Boca, G, D., \& Sarach, S. (2019). Environmental Education and Student's Perception, For Sustainability. Sustainability, 11(6), 1153. https://doi.org/10.3390/su11061553

[23] Warju, Harto, S. P., Soenarto, \& Hartmann, M. D. (2017). Evaluating the Implementation of Green School (Adiwiyata) Program: Evidence from Indonesia. International Journal of Environmental and Science Education, 12(6), 1483 - 1501. https://doi.org/ijese.2017.095

[24] Desfandi, M., Maryani, E., \& Disman. (2017). Building Ecoliteracy Through Adiwiyata Program (Study at Adiwiyata School in Banda Aceh. Indonesia Journal of Geography, 49(1), 51-56. https://doi.org/10.22146/ijg.11230

[25] Rosardi, R. G., \& Zuchdi, D. (2014). Pembelajaran IPS dengan Strategi Pemecahan Masalah untuk Meningkatkan Kemandirian dan Kepedulian Siswa. Harmoni Sosial: Jurnal Pendidikan IPS, 1(2), 190-203. https://doi.org/10.21831/hsjpi.v1i2.2440 
[26] McKeown-ice, R. (2015). Environmental Education: A Geographical Perspective. Journal of Geography, 93(1), 40-42. https://doi.org/10.1080/00221349408979684

[27] Hedden, M. K., Worthy, R., Akins, E., Friedman, V. S., \& Paul R. C. (2017). Teaching Sustainability Using an Active Learning Constructivist Approach: Discipline-Specific Case Studies in Higher Education. Sustainability, 9(8), 1320. https://doi.org/10.3390/su9081320

[28] Robottom, I. (2004). Contructivism in Environmental Education: Beyond Conceptual Change Theory. Australian Journal of Environmental Education, 20(2), 93-101. https://doi.org/10.1017/S0814062600002238

[29] Darner, R. (2014). Influences on Students' Environmental Self Determination and Implications for Science Curricula. International Journal of Environmental and Science Education, 9,21-39. https://doi.org/ 10.12973/ijese.2014.201a

[30] Ulutas, A. \& Köksalan, B. (2017). Investigation of Environmental Problem Solving Skills of Preschool Age Children. Research in Pedagogy, 7(2), 298 - 311. https://doi.org/10.17810/2015.66

[31] Lieung, K. W., Rahayu, D. P., Fredy \& Sulili, A. (2019). The influence of Scientific Approach on Environmental Problem Solving Skills in Elementary School Students. IOP Conf. Series: Earth and Environmental Science, 343, 1-5. https://doi.org/10.1088/1755$1315 / 343 / 1 / 012173$

[32] Aliman, M., Budijanto, Sumarmi, Astina, I. K. (2019). Improving Environmental Awareness of High School Students' in Malang City Through Earthcomm Learning in the Geography Class. International Journal of Instruction, 12(4), 79-94. https://doi.org/10.29333/iji.2019.1246a

[33] Hayati, W. I., Utaya, S., \& Astina, I. K. (2016). Efektivitas Student Worksheet Berbasis Project Based Learning dalam Menumbuhkan Kemampuan Berpikir Kritis Siswa pada Mata Pelajaran Geografi. Jurnal Pendidikan: Teori, Penelitian, dan Pengembangan, 1(3), 468474. http://dx.doi.org/10.17977/jp.v1i3.6174

[34] Greiff, S., Holt D. V., \& Funke J. (2013). Perspective on Problem Solving in Educational Assesment: Analytical, Interactive, and Collaborative Problem Solving. The Journal of Problem Solving. 5(2), 71-91. http://dx.doi.org/10.7771/1932-6246.1153

[35] Krulik, S., Rudnick, J., Milou, E. (2003). Teaching Mathematics in Middle School A Practical Guide. Boston. Pearson Education Inc.

[36] Adeoye, F.A. (2010). Effect of Problem Solving Skill and Cooperative Learning Strategies on Senior Secondary School Students' Achievement in Physics. Journal of Theory and Practice in Education. 6(1), 235-266.

[37] Suryawati, E. \& Osman, K. (2018). Contextual Learning: Innovative Approach toward the Development od Students' Scientific Attitude and Natural Science Performance. Eurasia Journal of Mathematics, Science and Technology Education. 14(1). 61-76. https://doi.org/10.12973/ejmste/79329

[38] Harun, N. F., Yusof, K. M., Jamaludin, M. Z., \& Hassan, S. A. H. S. (2012). Motivation in Problem-based Learning Implementation. Procedia-Social and Behavioral Sciences, 56, 233-242. https://doi.org/ 10.1016/j.sbspro.2012.09.650

[39] Levin, J. \& Milgrom, P. (2004). Introduction to Choice Theory.

[40] Dyer, J. S. \& Jia, J. (2013) Preferance Theory In: Gass S.I., Fu M.C. (eds) Encyclopedia of Operations Research and Management Science. Buston: Springer, Buston. https://doi.org/10.1007/978-1-4419-1153-7

[41] Chambers, C. P., Echenique, F., \& Shmaya, E. (2017). General revealed Preference Theory. Theoretical Economics, 12, 493 - 511. https://doi.org/ 10.3982/TE1924

[42] Johnson, E. S. (1984). Sex Differences in Problem Solving. Problem Solving, 13.

[43] D'Zurilla, T. J., Olivares, A. M., \& Kant, G. L. (1998). Age and Gender Differences in Social Problem Solving Ability. Personality and Individual Differences, 25, 241 - 252. 
Paper-Measuring Students Environmental Problem Solving Ability Across Gender and School Diff...

[44] Gallagher, A. M., Lisi, R. D., Holst, P. C., De lisi, A. V. M \& Cahalan, C. (2000). Gender Differences in Advanced Mathematical Problem Solving. Journal of Experimental Child Psychology, 75, 165 - 190. https://doi.org/10.1006/jecp.1999.2532

[45] Stoet, G., O'Connor, D. B., Conner, M., \& Laws, K. R. (2013). Are women better than men at multi-tasking? BMC Psychology, 1(1). https://doi.org/10.1186/2050-7283-1-18

[46] Rasiman. (2015). Leveling Of Students' Critical Ability In Solving Mathematics Problem Based On Gender Differences. International Journal of Education and Research, 3(4), 12.

[47] İleritürk, D. B. \& Kincal, R. Y. (2016). The Review of Variables Related to Problem Solving Skills in PISA 2003 - 2012 of Turkey. Sakarya University Journal of Education, 6(3), 40 53. https://doi.org/10.19126/suje.220179

[48] Mefoh, P. C., Nwoke, M. B., Chukwuorji, J. C., \& Chijioke, A. O. (2017). Effect of Cognitive Style and Gender on Adolscents' Problem Solving Ability. Thinking Skills and Creativity,

25 ,

47-52. https://doi.org/10.1016/j.tsc.2017.03.002

[49] Kusumaningsih, W., Darhim, Herman, T., \& Turmudi. (2018). Gender Differences In Algebraic Thinking Ability To Solve Mathematics Problems. Journal of Physics: Conference Series, 1013, 012143. https://doi.org/10.1088/1742-6596/1013/1/012143

[50] Karatas, I. \& Baki, A. (2013). The Effect of Learning Environments Based on Problem Solving on Students' Achievements of Problem Solving. International Electronic Journal of elementary Education, 5(3), 249 - 268.

[51] Al-Khateeb, M. A. (2018). The Effect of Teaching Mathematical Problem Solving Through Using Mobile Learning on The Seventh Grade Students' Abilitu to Solve them in Jordan. International Journal of Interactive Mobile Technologies, 12(3), $178-191$. https://doi.org/10.3991/ijim.v12i3.8713

[52] Turkkahraman, M. (2015). Education, teaching and School as A Social Organisation. Procedia Social abd Behavioral Sciences, 186, 381 - 387. https://doi.org/ 10.1016/j.sbspro.2015.04.044

[53] Sanjaya, W. (2008). Strategi Pembelajaran Berorientasi Standar Proses Pendidikan. Jakarta. Kencana Permada Media.

[54] Idris, B. K., Purnomo, A., Wiradimadja, A. \& Soekamto. (2019). Using Broadcasting Learning Design to Enhance Student's Experiental Skill. International Journal of Emerging Technologies in Learning, 14(16), 172 - 180. https://doi.org/10.3991/ijet.v14i16.10652

[55] Sari, R. M., Sumarmi, Astina, I. K., Utomo, D. H. \& Ridhwan. (2019). Measuring Students Scientific Learning Perception and Critical Thinking Skill Using Paper-Based Testing: $\underline{\text { School and Gender Defferences. International Journal of Emerging Technologies in Learn- }}$ ing, 14(9), 132-149. https://doi.org/10.3991/ijet.v14i19.10968

[56] Kalogiannakis, M. \& Papadakis, S. (2019). Evaluating Pre-service Kindergarten Teachers' Intention to Adopt and Use Tablets into Teaching Practice for Natural Sciences. International Journal of Mobile Learning and Organisation, 13(1), 113-127. https://doi.org/ 10.1504/IJMLO.2019.096479

[57] Yuwono, A. (2016). Problem Solving dalam Pembelajaran Matematika. Union=Jurnal Pendidikan Matematika. 4(1). 143-156. http://dx.doi.org/10.30738/.v4i1.420

[58] Bukit, N. \& Mihardi, S. (2012). The Effect of Learning Physics With Problem Based Instruction (PBI) Models in Physycs at the Classroom. Jurnal Pendidikan Fisika. 1(1). 1-8. https://doi.org/10.22611/jpf.v1i1.3374

[59] Patnani, M. (2013). Upaya Meningkatkan Kemampuan Problem Solving Pada Mahasiswa. Jurnal Psikogenesis. 1(2). 130-142. https://doi.org/10.24854/jps.v1i2.43

[60] Irwanto, I., Saputro, A.D., Rohaeti, E., \& Prodjosantoso, A. K. (2018). Promoting Critical Thinking and Problem Solving Skills of Preservice Elementary Teachers through ProcessOriented Guided-Inquiry Learning (POGIL). International Journal of Instruction, 11(4), 777-794. https://doi.org/10.12973/iji.2018.11449a 
Paper-Measuring Students Environmental Problem Solving Ability Across Gender and School Diff...

[61] Soltanzadeh, L., Hashemi, S. R.N., \& Shahi, S. (2013). The Effect of Active Learning on Academic Achievement Motivation in High Schools Students. Archives of Applied Science Research. 5(6). 127-131.

[62] Shamaki, T. A., (2015). Influence of Learning Environment on Student's Academic Achievement in Mathematics: A Case Study of Some Selected Secondary Schools in Yobe State - Nigeria. Journal of Education and Practice. 6(34). 40-44

[63] Angreranti, M, \& Malihah, N. (2017). The Influence of School Environment and the Performance of The Honorary Teachers of Islamic Education Toward the Learning Achievements. Mudarrisa: Jurnal Kajian Pendidikan Islam. 9(2).248-266. https://doi.org/ 10.18326/mudarrisa.v9i2.248-266

[64] Yoshida, M. (2018). An Investigation of the Social Network System Competencies of High School Students in Japan. International Journal of Emerging Technologies in Learning. 13(5). 4-18. https://doi.org/10.3991/ijet.v13i05.8101

[65] Erhabor, N. I. \& Don, J. U. (2016). Impact of Environmental Education On the Knowledge and Attitude of Students Towards the Environment. International Journal of Environmental and Science Education, 11(12), 5367 - 5375. https://doi.org/ijese.2016.399

[66] Argaw, A. S., Haile, B. B., Ayalew, B. T., \& Kuma, S. G. (2017). The Effect of Problem Based Learning (PBL) Instruction on Students' Motivation and Problem Solving Skills of Physics. Eurasia Journal of Mathematics, Science and Technology Education. 13(3). 857871. https://doi.org/10.12973/eurasia.2017.00647a

[67] Anggraini, L, Siroj, R. A., \& Ilma, R. (2010). Penerapan Model Pembelajaran Investigasi Kelompok untuk Meningkatkan Kemampuan Pemecahan Masalah matematika Siswa Kelas VIII-4 SMP Negeri 27 Palembang. Jurnal Pendidikan Matematika. 4(1). https://doi.org/10.22342/jpm.4.1.309.

[68] Simamora, R. E., Sidabutar, D. R., \& Surya, E. (2017). Improving Learning Activity and Students Problem Solving Skill Through Problem Based Learning (PBL) in Junior High School. International Journal of Sciences: Basic and Applied Researc. 33(2). 321-331

[69] Anisah, \& Lastuti, S. (2018). Pengembangan Bahan Ajar berbasis HOTS untuk Meningkatkan Kemampuan Pemecahan Masalah Matematis Mahasiswa. 9(2). 191-197. http://dx.doi.org/10.15294/kreano.v9i2.16341

[70] Maula, N. Rochmad, Soedjoko, E. (2014). Keefektifan Pembelajaran Model Tapps Berbantuan Worksheet Terhadap Kemampuan Pemecahan Masalah Materi Lingkaran. Jurnal Pendidikan Matematika dan Sains, 2(1), 19-27. https://doi.org/ 10.21831/jpms.v3i1.3889

[71] Nurfadilah, U., \& Suhendar, U. (2019). Pengaruh Penggunaan Geogebra Terhadap Kemampuan Pemecahan Masalah Siswa Pada Topik Garis dan Sudut. JMPM=Jurnal Matematika dan Pendidikan Matematika. 3(2). 84-98. https://doi.org/10.26594/jmpm.v3i2.1294

[72] Suryawati, E., Osman, K. \& Meerah, T. S. M. (2010). The Effectiveness of RANGKA Contextual Teaching and Learning on Students' Problem Solving Skills and Scientific Attitude. Procedia Social and Behaviour Sciences. 9: 1717-1721. https://doi.org/10.1016/j.sbspro. 2010.12.389

[73] Lay, Y. F. (2019). Integrating Environmental Education and ICT. Eurasia Journal of Mathematics, Science, And Technology Education, 15(5), 1-3. ttps://doi.org/10.29333/ejmste/ $\underline{105686}$

\section{References}

Ridhwan is doctoral student and researcher at the Geography Education Program, Faculty of Social Science, Universitas Negeri Malang, Jl. Semarang No. 5, Malang, Jawa Timur, Indonesia and a lecturer at the Geography Education Program, STKIP A1Washliyah, Banda Aceh, Indonesia. 
Sumarmi is a Professor, Researcher, and senior lecturer at the Geography Education Program, Faculty of Social Science, Universitas Negeri Malang, Jl. Semarang No. 5, Malang, Jawa Timur, Indonesia.

I Nyoman Ruja is a senior lecturer at the Social Science Education Program, Faculty of Social Science, Universitas Negeri Malang, Jl. Semarang No. 5, Malang, Jawa Timur, Indonesia.

Dwiyono Hari Utomo is a senior lecturer at the Geography Education Program, Faculty of Social Science, Universitas Negeri Malang, Jl. Semarang No. 5, Malang, Jawa Timur, Indonesia.

Rima Meilita Sari is a lecturer at the Geography Educational Program, STKIP AlWashliyah, Banda Aceh, Indonesia.

Article submitted 2019-09-19. Resubmitted 2020-01-21. Final acceptance 2020-02-01. Final version published as submitted by the authors. 